\title{
The Valuation of Non-Performing Loans
}

\author{
Muslih $^{1}$, Hazmanan Khair ${ }^{2}$, Januri $^{3}$, Ade Gunawan ${ }^{4}$, M. Firza Alpi ${ }^{5}$ \\ \{muslihekonomi@gmail.com ${ }^{1}$, hazmananpasaribu@gmail.com², januri@umsu.ac.id ${ }^{3}$, \\ adegunawan@umsu.ac.id ${ }^{4}$,m.firzaalpi@umsu.ac.id $\left.{ }^{5}\right\}$ \\ 1,2,3,4,5 University of Muhammadiyah Sumatera Utara, Jalan Kapten Mukhtar Basri No. 3 Medan, \\ Indonesia
}

\begin{abstract}
This study aims to determine and evaluate the NPLs supervision made by the bank so that the net profit. The study was conducted at Head Office PT. Bank Sumut, Medan, North Sumatra, Indonesia. The type of data used in this research report in the form of financial statements of financial position and statement of income for the year 2011 to 2015. The data analysis method used is the method of analysis of NPLs by calculating and then analyze the results of the NPLs and the results showed that credit monitoring conducted by Head Office PT. Bank Sumut, yet provide maximum results with a proven increase in the number of NPLs in the last 5 years are classified in the category of unhealthy which results in decreased levels of net profit generated in the Central Office PT. Bank of Sumut, Medan, so the Bank must improve oversight of NPLs so that maximum profit can be generated.
\end{abstract}

Keyword: Net income, Nonperforming Loans

\section{Intorduction}

Non-performing loans (NPLs) are loans where the borrower does not make payments in accordance with the agreed obligations. NPLs will run into problems if the customer does not pay back the value of the contract (Bholat, et al., 2016). A commercial bank is a financial institution that is most dominant in most of the economy of a country, and the existence of a commercial bank in a country will accelerate the process of economic growth, while the Bank unhealthy conditions will impact a barrier to economic growth. Some of the existing loans in the bank cannot run properly non-performing loans is not as expected by banks (Omwenga and Omar, 2012); (Rajha, 2017). One source of the Bank's income is loan; while the bank's main goal is to get the maximum profit with so many banks is lending money to the community. When providing bank loans should be to carefully avoid and minimize the risk of bad debts in order not to cause bankruptcy (Chandraningtyas, et al., 2013), (Saba, et al., 2012). According to Bank Indonesia Regulation Number 6/10/PBI/2004 12 $2^{\text {th }}$ April 2004, Rating System For Commercial Banks, assessment of asset quality aspect is based on the calculation of Non-Performing Loans (NPLs), NPLs indicates the level of troubled loans from the bank's total loans to the public.

In the opinion of (Adhikary, 2006) describes the credit assessment qualitatively, can be grouped in any loan if the loan recovery due to various reasons such as extended credit without approval authority, the information is incomplete, inadequate security, frequent overdraw of limits, filed a lawsuit against a loan for credit recovery. In the rules of the financial system centered on the Bank, NPLs may be an option in an economic recovery by minimizing capital of banks to advance loans.

Previous research explains that one of the factors of bad loans in some countries such as Italy, Spain, and Greece, nonperforming loans increased when the unemployment rate and the real interest rate rises, and will according to current GDP growth rates and lower asset 
profitability (Cucinelli, 2015), while (Adebisi and Benjamin, 2015); (Thomas, et al., 2008) on the findings reveal the challenges in dealing with bad credit, that banks should ensure that customers will make payments on time, while the level of NPLs are high will impact bank balance sheets, the possibility of adverse effects on bank lending (Klein, 2013); (Anjom and Karim, 2016).

PT. Bank of North Sumatra is one of the bank's status as a Regional Development Bank (BPD) in the form of a Limited Liability Company (PT), the bank has branches in North Sumatra North Sumatra area, Based on observations Authors found on most customers experience the process of bad credit due to a mismatch between the amount of collateralized loans, so that the customer's ability to repay the loan does not comply with the contract value. Some of the reasons given by the customer, the employee PT. Bank of Sumut also pay less attention to the application of credit ratings as measured Character, Capacity, Capital, Condition Collateral and customers, to make loans to customers. According to Act of the Republic of Indonesia No.10 of 1998, Credit is the provision of cash or equivalent was based on agreements borrowing and lending between banks and other parties who require the borrower to repay the debt after a certain period of time with interest. Further research by Clementina and Isu, (2014); Khan and Ahmad, (2017), said that in the banking system, the problem of bad loans consisted of old unproductive debt and new loans are not running properly and will have an impact on bank performance. It is important to identify the factors that affect the NPLs and provide some solutions to banks, in accordance with the opinion (Anastasiou et al., 2005) which says that banks should increase credit policy and supervision.

Then according (Messai \& Jouini, 2013) minimize NPLs is a condition that is needed to boost economic growth. If NPLs maintained, this will have an impact on resources that are not profitable, thus NPLs are likely to hamper economic growth and reduce economic efficiency and shocks to the financial system banking.

Economic growth cannot be achieved without a healthy banking system is good, that the high debt could slow growth and will lead to financial instability, low-interest rates per capita and higher interest rates may also produce the low capacity and can be bad loans (Ikram et al., 2016).

According to the author, some researchers in other countries have been testing NPLs, which previous studies have analyzed the determinants of NPLs, that determinants of NPLs in some countries have used aggregate data for the banking system as research (Kjosevski \& Petkovski, 2017). Then they explained by the literature that NPLs into three parts, the first focusing on NPLs in institutions Credit in each country, indicating the role of macroeconomic performance, quality of management, the second, the relationship between the NPL and the financial condition of the macro, and the third focuses on predicting NPLs at a macro level, is related circuitry aggregate total loans (total debt) or a certain type of loans.

\section{Methods}

This study used a descriptive approach to a study conducted by collecting and presenting data obtained from the company to describe a phenomenon of the problem and analyze it into a conclusion. The type of data used in this research is financial statements and the Income Statement PT. Bank of North Sumatra Medan Central Office, namely the balance sheet and income statement in 2011 until 2015. Then do a thorough analysis of the NPLs that occurred at PT. Bank of Sumut. 


\section{Results}

\subsection{Data Presentation}

NPLs is the failure of the debtor to meet its obligations to pay installments. The level of credit risk are reviewed with due NPLs, can be used to measure the extent of non-performing loans can be fulfilled with assets owned by a bank.

Table 1. Non Performing Loan (NPLs) PT.Bank of Sumut.

\begin{tabular}{cccccc}
\hline Years & $\begin{array}{c}\text { Less } \\
\text { Smoothly }\end{array}$ & Doubtful & $\begin{array}{c}\text { Bad } \\
\text { Credit }\end{array}$ & $\begin{array}{c}\text { Credit } \\
\text { Given }\end{array}$ & NPL \\
\hline 2011 & 10.584 & 18.061 & 275.626 & 11.001 & 2,56 \\
\hline 2012 & 2.760 & 31.524 & 376.230 & 15.325 & 2,81 \\
\hline 2013 & 68.228 & 44.528 & 542.616 & 17.109 & 3,83 \\
\hline 2014 & 82.712 & 75.705 & 833.671 & 18.161 & 5,47 \\
\hline 2015 & 62.193 & 75.558 & 797.722 & 18.696 & 5 \\
\hline
\end{tabular}

Source: Financial Statement Data PT. Bank of Sumut, Head Office.

NPLs $=\quad$ Total NPL/Total Credits $\times 100 \%$

Calcuation :

$2011: \mathrm{NPL}=384.271 / 11.885 \times 100=2,56$

2012: $\mathrm{NPL}=430.514 / 15.325 \times 100=2,81$

2013: $\mathrm{NPL}=655.362 / 17.109 \times 100=3,83$

2014: $\mathrm{NPL}=992.088 / 18.161 \times 100=5,47$

2015: NPL $=935.473 / 18.696 \times 100=5$

Table 1, it is known NPLs for 2011 to 2015 has increased. In 2011, for NPLs by $2.56 \%$, while for the year 2012 increased by $2.81 \%$. Likewise for the years 2013 to 2014 also increased to $3.83 \%$ and $5.47 \%$ this is due to an increase in problem loans at PT. Bank of North Sumatra, as well as for 2015, NPLs increased to 5\%. This indicates that the PT. Bank of North Sumatra in a state that is not very good, because of a lot of unproductive funds that occurred in North Sumatra bank, which will have an impact on reducing profitability.

\subsection{Net Income}

Net income the excess of all revenues on the entire cost for a certain period after deducting income tax presented in the income statement. The last figure in the income statement is net income, this number represents a net increase of the capital. Conversely, if the company suffers a loss, the last figure in the income statement is Net Loss.

Tabe1 2. Net Income PT. Bank of Sumut (in the billions IDR).

\begin{tabular}{cccc}
\hline Year & revenue & Expense & Net Income \\
\hline 2011 & 2.260 & 1.834 & 426 \\
\hline 2012 & 2.538 & 2.116 & 422 \\
\hline 2013 & 2.706 & 2.174 & 532 \\
\hline 2014 & 2.959 & 2.494 & 465 \\
\hline 2015 & 3.477 & 3.011 & 465 \\
\hline
\end{tabular}

Source: Financial Statement PT.Bank of Sumut Kantor Pusat. 
Net Income $=$ Revenue - Expense

Calculation:

$2011:$ Net Income $=2.260-1.834=426$

$2012:$ Net Income $=2.538-2.116=422$

$2013:$ Net Income $=2.706-2.174=532$

$2014:$ Net Income $=2.959-2.494=465$

$2015:$ Net Income $=3.477-3.011=465$

Table 2, known to Net Income for the year 2011 to 2015 experienced ups and downs. Net profit in 2011 amounted to 426 IDR, while for the year 2012 decreased by 422 IDR. Likewise, for the year 2013 increased significantly by 532 IDR and in 2014 and 2015 decreased by 465 IDR. This shows that in North Sumatra bank in a state that is not very good, because of reduced profits in every year of observations that occur in the PT. Bank of Sumut, which have an impact on reducing Net Income.

\section{Discussion}

The results obtained on Non-Performing Loans (NPLs), for the years 2011 to 2015, NPLs increased. Even in 2014, NPLs increased and exceeds state standards of Bank Indonesia Regulation which states for a maximum of $5 \%$ NPLs.

According To Regulations Bank Indonesia Number 6/10/PBI/2004 Date April, 12 2004, Rating System For Commercial Banks, the higher non-performing loans (NPLs) above 5\% then the bank is not healthy. This suggests that the Bank of North Sumatra in a state that is not very good, because of a lot of unproductive funds that occurred at PT. Bank of North Sumatra, which will have an impact on reducing net profit at PT. Bank of Sumut. Supervision and assessment in providing credit loans are not optimal, so wrong in making decisions in credit control and customer late in making payments on loans, besides the bad loans increased, this happens due to PT. Bank of North Sumatra less cautious in providing financing to customers, such opinions (Akhter and Kumar, 2017) one of his solutions is to reduce bad loans and ensure a healthy banking performance. Non-Performing Loans (NPLs) experienced an increase in PT. Bank of North Sumatra, due to the credit control was not good from PT. Bank of Sumut. Supervision is not good can be seen from the increasing number of bad loans on banks, as in 2014, NPLs by 5:47 which caused net income fell to RP. 465, so a lot of funds that are embedded in such loans, it causes will increase the amount of credit risk is also increased, due to the increasing amount of credit that occurred due to borrowers who are not punctual in paying for credit and supervision unfavorable from the company to potential debtors. Therefore, like the opinion Bhattarai, (2014), Haneef et al., (2012), Singh, (2016) which states that banks should reduce bad loans and can lend to other sectors deemed appropriate, and strengthen supervision of NPLs.

One way to minimize the risk of the loan is to make certain rules in and establish an independent body such as the audit committee, the credit committee, and the risk committee and can control the internal operation of the bank and surveillance before audited by an external auditor. The credit committee in charge of examining and formulating finance activities of the credit system, the risk committee in charge of managing and accessing the risks arising from banking activities. The monitoring system conducted by the committee would reduce the discretion of the manager in the lending and can control non-Performing Loans (Saada, 2018), likewise described by, the ratio of non-performing loans with the bank's 
profitability showed that there was a higher level of provision of losing the loan is charged to earnings and ultimately leads to reduce bank profitability (ROA), the bank's management to take corrective action early to keep NPLs as low as possible which will allow it to maintain the high profitability of commercial banks.

For this study corroborates the findings as proposed by Chaibi, (2016) that the assessment of overall asset quality in the banking industry is an important element in supervision. Inefficiency and profitability of banks seem to be the deciding factor significantly affecting the credit risk as measured by means of qualitative and quantitative, quality of bank management is the most important indicator to reduce bad loans in the future, therefore, the importance of managerial performance so as to minimize the potential for increased credit risk. The bank's policy in lending should be able to implement policies that tight credit risk management can anticipate the increase in bad debts linked to the increase in bank lending, the Bank of Sumut in order to assess the financial stability as stated Ntow \& Alu, (2016) that banks should be careful in making changes in credit policy, due to the bad loans will affect macroeconomic variables of a country in the future.

Therefore, the bank must know the condition of the prospective customer before granting loans, NPLs due to the borrower requires conducting the investigation in an authentic customer in order to safeguard financial stability in the banking system. The high level of NPL requires banks to raise provisions on loan losses reduced banks' income and reduce funds for new loans (Anjom and Karim, 2016).

\section{Conclusions}

Financial performance. Bank of North Sumatra Medan Central Office by using financial ratios that have been set by According To Regulations Bank Indonesia Number 6/10/PBI/2004 Date April, 12 2004, Rating System For Commercial Banks, the higher non-performing loans (NPLs) ratio above 5\% then the bank is not healthy. So we can conclude the level of NPLs in PT. Bank of Sumut is not very good, this can be evidenced by the increasing number of NPLs in the last 5 years are classified in the category of unhealthy resulting in a decrease in Net Income is generated by PT. Bank of North Sumatra Medan Head Office, Factors that cause the bad loans that take place between them was an oversight that inadvertently in to provide financing to customers, bank weaknesses in the analysis leading to errors in decision-making, as well as delinquency and weaknesses customers in paying their obligations.

\section{References}

[1] Adebisi, J. F. and Benjamin, O. (2015) 'The Impact of Non-Performing Loans on Firm Profitability: A Focus on the Nigerian Banking Industry', American Research Journal of Business and Management, 1(4), pp. 1-7. doi: ISSN: 2379-1047.

[2] Adhikary, B. K. (2006) 'Nonperforming Loans in the Banking Sector of Bangladesh: Realities and Challenges', Bangladesh Institute of Bank Management, pp. 75-95.

[3] Akhter, S. and Kumar, J. (2017) 'Analysis of Credit Risk, Efficiency , Liquidity , and Profitability of Selected Non-Bank Financial Institution : An Empirical Study', Journal of Business, 02(02), pp. 16-23.

[4] Anastasiou, D., Lour, H. and Tsionas, M. G. (2005) Non-performing loans in the euro area: are core-periphery banking markets fragmented? 219. Athens, Greece.

[5] Anjom, W. and Karim, A. M. (2016) 'Relationship Between Non-Performing Loans And Macroeconomic Factors With Bank Specific Factors: A Case Study On Loan Portfolios - Saarc Countries Perspective', Elk Asia Pacific Journal Of Finance And 
Risk Management Issn, 7(3), pp. 1-30. doi: 10.16962/EAPJFRM/issn.

[6] Bhattarai, S. (2014) 'Determinants of Non-Performing Loans: Perception of Nepali Bankers', Economic Journal of Development Issues, 17 \& 18(1-2), pp. 128-148. doi: 10.2298/PAN1402193M.

[7] Bholat, D. et al. (2016) Non-Performing Loans: Regulatory and Accounting Treatments of Assets, SSRN Electronic Journal. doi: 10.2139/ssrn.2768865.

[8] Chaibi, H. (2016) 'Determinants of Problem Loans: Non-performing Loans vs. Loan Quality Deterioration', International Business Research, 9(10), pp. 86-93. doi: 10.5539/ibr.v9n10p86.

[9] Chandraningtyas, I., Musadieq, M. A. and Utami, H. N. (2013) 'Pengaruh Kepuasan Kerja Dan Motivasi Kerja Terhadap Kinerja Karyawan Melalui Komitmen Organisasional (Studi pada karyawan PT. Kusuma Karya Persada yang outsourcing di PT. Sasa Inti Probolinggo)', Jurnal Profit, 6(2), pp. 32-43.

[10] Clementina, K. and Isu, H. O. (2014) 'No TitleThe rising incidence of non-performing loans and the nexus of economic performance in nigeria: an investigation', European Journal of Accounting Auditing and Finance Research, 2(5), pp. 87-96.

[11] Cucinelli, D. (2015) 'The Impact of Non-performing Loans on Bank Lending Behavior: Evidence from the Italian Banking Sector', Eurasian Journal of Business and Economics, 8(16), pp. 59-71. doi: 10.17015/ejbe.2015.016.04.

[12] Haneef, S. et al. (2012) 'Impact of Risk Management on Non-Performing Loans and Profitability of Banking Sector of Pakistan', International Journal of Business and Social Science, 3(7), pp. 307-315.

[13] Ikram, A. et al. (2016) 'Determinants Of Non-Performing Loans: An Empirical Investigation Of Bank- Specific Microeconomic Factors', The Journal of Applied Business Research, 32(6), pp. 1723-1736.

[14] Khan, I. and Ahmad, A. (2017) 'Assessing Banks Internal Factors as Determinants of Non-Performing Loans: Evidence from Pakistani Commercial Banks', Journal of Managerial Sciences, 11(1), pp. 109-125.

[15] Kjosevski, J. and Petkovski, M. (2017) 'Non-performing loans in Baltic States: determinants and macroeconomic effects', Baltic Journal of Economics. Taylor \& Francis, 17(1), pp. 25-44. doi: 10.1080/1406099X.2016.1246234.

[16] Klein, N. (2013) Non-Performing Loans in CESEE: Determinants and Impact on Macroeconomic Performance, IMF Working Papers. doi: 10.5089/9781484318522.001.

[17] Messai, A. S. and Jouini, F. (2013) 'Micro and Macro Determinants of Non-performing Loans', International Journal of Economics and Financial Issues, 3(4), pp. 852-860. doi: $10.1300 / \mathrm{J} 079 \mathrm{v} 27 \mathrm{n} 0402$.

[18] Ntow, E. L. M. and Alu, G. A. A. (2016) 'Nonperforming loans and bank profitability: evidence from an emerging market', African Journal of Economic and Management Studies, 7(4), pp. 462-481. doi: 10.1108/AJEMS-07-2015-0088.

[19] Omwenga, N. K. and Omar, N. (2012) 'The Effects of Board Diversity on the Financial Performance of Commercial Banks in Kenya', International Journal of Business and Social Research, 1(2), pp. 25-29.

[20] Rajha, K. S. (2017) 'Determinants of Non-Performing Loans: Evidence from the Jordanian Banking Sector', Journal of Finance and Bank Management, 4(1), pp. 125136. doi: 10.15640/jfbm.v5n1a5.

[21] Saada, M. Ben (2018) 'The impact of control quality on the non-performing loans of Tunisian listed banks', Managerial Auditing Journal, 33(1), pp. 2-15. doi: 
10.1108/MAJ-01-2017-1506.

[22] Saba, I., Kouser, R. and Azeem, M. (2012) 'Determinants of Non Performing Loans: Case of US Banking Sector', The Romanian Economic Journal, 15(January), pp. 141152.

[23] Singh, V. R. (2016) 'A Study of Non-Performing Assets of Commercial Banks and it ' $\mathrm{s}$ recovery in India', Annual Research Journal of SCMS, Pune, 4(March), pp. 110-125.

[24] Thomas, W. ., Lau, T. and Snape, E. (2008) 'Entrepreneurial Competencies and the Performance of Small and Medium Enterprises: An Investigation through a Framework of Competitiveness', Journal of Small Business \& Entrepreneurship, 21(3), pp. 257276. doi: $10.1080 / 08276331.2008 .10593424$. 